\title{
Correction to: Large deformation plasticity
}

\section{O. T. Bruhns ${ }^{1}$}

Published online: 8 November 2021

(C) The Author(s) 2021

\section{Correction to:}

Acta Mech. Sin.

https://doi.org/10.1007/s10409-020-00926-7

The article 'Large deformation plasticity From basic relations to finite deformation, written by Otto T. Bruhns, was originally published Online first without open access. After publication in volume [36], issue [2], page [472-492] the author decided to opt for Open Choice and to make the article an Open Access publication. Therefore, the copyright of the article has been changed to (c) The Authors 2021 and the article is forthwith distributed under a Creative Commons Attribution 4.0 International License, which permits use, sharing, adaptation, distribution and reproduction in any medium or format, as long as you give appropriate credit to the original author(s) and the source, provide a link to the Creative Commons licence, and indicate if changes were made. The images or other third party material in this article are included in the article's Cre- ative Commons licence, unless indicated otherwise in a credit line to the material. If material is not included in the article's Creative Commons licence and your intended use is not permitted by statutory regulation or exceeds the permitted use, you will need to obtain permission directly from the copyright holder. To view a copy of this licence, visit http://creativecommons.org/licenses/by/4. 0 . Open access funding enabled and organized by Projekt DEAL.

The original article has been corrected.

Open Access This article is distributed under the terms of the Creative Commons Attribution 4.0 International License (http://creativecomm ons.org/licenses/by/4.0/), which permits unrestricted use, distribution, and reproduction in any medium, provided you give appropriate credit to the original author(s) and the source, provide a link to the Creative Commons license, and indicate if changes were made.
The original article can be found online at https://doi.org/10.1007/ s10409-020-00926-7.

\footnotetext{
$\triangle$ O. T. Bruhns

otto.bruhns@rub.de

1 Institute of Mechanics, Ruhr-University Bochum, 44780 Bochum, Germany
} 